\title{
Carnets
}

Revue électronique d'études françaises de l'APEF

Première Série - 4 | 2012

(Res)sources de l'extravagance

\section{Sentidos da extravagância dos contos em Le Sopha e Ah Quel Conte! de Claude Crébillon}

Ana Alexandra Seabra De Carvalho

\section{OpenEdition}

1 Journals

\section{Edição electrónica}

URL: http://journals.openedition.org/carnets/6670

DOI: $10.4000 /$ carnets. 6670

ISSN: 1646-7698

\section{Editora}

APEF

\section{Edição impressa}

Data de publição: 1 Janeiro 2012

Paginação: 63-84

\section{Refêrencia eletrónica}

Ana Alexandra Seabra De Carvalho, «Sentidos da extravagância dos contos em Le Sopha e Ah Quel Conte! de Claude Crébillon », Carnets [Online], Première Série - 4| 2012, posto online no dia 20 junho 2018, consultado o 01 maio 2019. URL : http://journals.openedition.org/carnets/6670 ; DOI :

$10.4000 /$ carnets. 6670

\section{(c) (1) (8)}

Carnets est mis à disposition selon les termes de la licence Creative Commons - Atribution - Pas d'utilisation commerciale 4.0 International. 


\title{
SENTIDOS DA EXTRAVAGÂNCIA DOS CONTOS EM LE SOPHA E AH QUEL CONTE! DE CLAUDE CRÉBILLON
}

\author{
Ana Alexandra Seabra de Carvalho \\ Universidade do Algarve \\ CLEPUL \\ aacarva@ualg.pt
}

\begin{abstract}
Resumo
Em Le Sopha e Ah quel Conte!, Crébillon recorre à extravagância para problematizar o exotismo maravilhoso na literatura coeva e propor uma reflexão sobre questões de natureza moral e política. Metempsicose, metamorfoses, encantamentos, extraídos do vasto fundo de motivos do conto maravilhoso, alimentam a imaginação criadora do autor, que, fiel à ironia da sua poética do jogo, se serve da bizarria feérica e orientalizante para criticar os costumes, à maneira da comédia molieresca. O desvelar decente das máscaras sociais insere-se numa busca do verdadeiro amor, o qual não corresponde à ideologia preciosa, mas deve integrar harmoniosamente "le cœur, l'esprit et les sens", algures entre o amor puro inacessível e o puro desejo mascarado de falso sentimento. Estes contos galantes orientais são, pois, obras ao serviço de uma visão irónica e céptica da sociedade.
\end{abstract}

\begin{abstract}
In Le Sopha and Ah quel Conte!, Crébillon turns to extravagance in order to question marvellous exoticism in coeval literature and to propose careful consideration about some issues of both moral and political nature. Metempsychosis, metamorphoses, enchantments, extracted from the vast background of fairy tales' motives, stimulate the author's creative imagination, who, loyal to his ironic poetics of game, uses the extravagant and oriental-like fairy tales to criticize morals, in the way of Molière's comedy. Decent disclosure of social masks is inserted in the quest for true love, which does not correspond to precious ideology, but should instead harmoniously combine "le cœur, l'esprit et les sens", somewhere between inaccessible pure love and sheer desire masked with false feelings. These oriental and gallant fairy tales are therefore texts in the service of an ironic and sceptical view of society.
\end{abstract}

Palavras-chave: Crébillon, conto, crítica social e literária

Keywords: Crébillon, tale, social and literary criticism 
II en faut beaucoup pour faire des contes! Ne dirait-on pas, à vous entendre, qu'un Conte est le chef-d'œuvre de l'esprit humain? Et cependant, quoi de plus puéril, de plus absurde? Qu'est-ce qu'un ouvrage (s'il est vrai toutefois qu'un Conte mérite de porter ce nom), qu'est-ce, dis-je, qu'un ouvrage où la vraisemblance est toujours violée, et où les idées reçues sont perpétuellement renversées; qui, s'appuyant sur un faux et frivole merveilleux, n'emploie des êtres extraordinaires, et la toute-puissance de la Féerie, ne bouleverse l'ordre de la Nature, et celui des Éléments, que pour créer des objets ridicules, singulièrement imaginés, mais qui souvent n'ont rien qui rachète l'extravagance de leur création? Trop heureux encore si ces misérables fables ne gâtaient que l'esprit, et n'allaient point par des peintures trop vives, et qui blessent la pudeur, porter jusques au cœur des impressions dangereuses?

Claude Crébillon ${ }^{1}$

Partindo do conceito de "extravagância" como sinónimo de ruptura com o racionalismo aristotélico e o princípio da imitação, propomos neste artigo uma leitura de Le Sopha e Ah quel Conte! de Claude Prosper Jolyot de Crébillon (1707-1777), onde analisaremos o modo como o autor recorre à extravagância para problematizar o exotismo maravilhoso na literatura coeva, bem como sugerir uma reflexão sobre questões de natureza moral e política. Depois do sucesso de Le Sylphe e do escândalo provocado pela sua primeira incursão no conto galante de perfume oriental (L'Écumoire), que conduz o autor à prisão e o livro à fogueira, Crébillon reincide na fórmula como meio de divertir moralizando através da análise psicológica, que problematiza o mito do amor perfeito e a hipocrisia da "extrêmement bonne compagnie" coeva. Publica, então, uma suposta continuação das Mil e Uma Noites intitulada Le Sopha, conte moral $(1742)^{2}$, vendo-se condenado a três meses de exílio de Paris. Mais de uma década depois, faz surgir uma espécie de continuação promissoramente designada Ah quel Conte! Conte politique et astronomique $(1754)^{3}$. A censura, sob a capa da extravagância feérica e oriental - roçando mesmo a loucura no último texto -, julgou descobrir o erotismo libertino e a impertinência para com as instituições políticas e religiosas. Contudo, se é verdade que a extravagância encobre com o seu manto diáfano e precioso uma realidade bem mais crua, o autor não defende a libertinagem. Metempsicose, metamorfoses, encantamentos, todo o vasto fundo de motivos do conto

\footnotetext{
${ }^{1}$ Crébillon (2000: 286).

2 Para uma história das atribulações das sucessivas edições da obra ver a introdução de J. Sgard (Crébillon, 2000: 251-280 e 735-751).

${ }_{3}^{3}$ Para uma história das atribulações das sucessivas versões da obra ver a introdução de R. Jomand-Baudry (Crébillon, 2001: 275-297 e 647-653).
} 
maravilhoso alimentam perfeitamente a imaginação criadora de Crébillon que, de acordo com a ironia da sua poética do jogo, coloca a bizarria feérica e orientalizante ao serviço da crítica dos costumes, à maneira da comédia molieresca. Tal como afirma no prefácio dos Égarements, o seu projecto visa transformar o romance, género depreciado pelos doutos seus contemporâneos, no espelho do homem tal como ele é, censurando os seus vícios e ridículos. Nas duas obras que aqui nos ocupam, esta utilidade moral da pintura da vida humana efectua-se através da utilização das convenções do maravilhoso, mas pervertendoas. Com efeito, Crébillon explora os motivos do género maravilhoso exótico e oriental, mas para os modificar e adaptar aos seus propósitos. Por outro lado, o desvelar decente das máscaras sociais insere-se numa busca do verdadeiro amor, o qual não corresponde à ideologia preciosa do século anterior, mas deve integrar harmoniosamente "le cœur, l'esprit et les sens", algures entre o amor puro inacessível e o puro desejo mascarado de falso sentimento. Estes dois contos galantes orientais são, pois, obras ao serviço de uma visão irónica e céptica da sociedade.

A partir de 1729, com a idade de vinte e dois anos, Claude Crébillon traça o seu destino com toda a clareza, ao decidir trocar os doutos ensinamentos da Companhia de Jesus pelos da companhia boémia da Comédia Italiana. Nascido e criado no meio teatral, devido à circunstância de ser filho do "Grand Crébillon" (o rival de Voltaire no campo da tragédia), "Le Petit", como alguns Ihe chamavam, revela, porém, desde cedo, uma nítida preferência pelo género cómico, ao iniciar a sua carreira de escritor com Le Sylphe, ou songe de Madame de $R^{* * *}$, écrit par elle-même à Madame de $S^{* * *}(1730)$. Trata-se de um pequeno conto que problematiza já o código do conto maravilhoso herdado do século anterior, nomeadamente, ao eleger a teatralidade da forma dialogada através da conversa estabelecida entre a voz do sedutor invisível (um silfo) e a Condessa sua interlocutora, a qual acumula os papéis de protagonista e narradora da história, visto que é ela quem, num registo autodiegético, conta a sua aventura nocturna, ou o seu devaneio onírico, a uma amiga, sob a forma do diálogo epistolar. Após esta estreia, que lança a moda literária e teatral dos silfos e sílfides, segue-se, em 1732, uma monódia epistolar intitulada Lettres de la Marquise de $M^{* * *}$ au Comte de $R^{* * *}$, obra que conhecerá, igualmente, um grande sucesso, explorando e inovando o código da convenção ficcional da autenticidade das cartas. Em 1734, Crébillon regressa à fórmula do conto maravilhoso com a publicação de Tanzaï et Néadarné, histoire japonaise, obra mais conhecida como L'Écumoire. Contudo, o artifício literário, mescla da paródia do conto oriental com a do conto de fadas, escolhido para enganar a censura quanto à feroz crítica religiosa, política e social encenada no texto não é suficiente para evitar ao autor o aborrecimento de alguns dias de cadeia e para salvar a obra da condenação à fogueira. 
Nos anos seguintes, Crébillon escreve alguns dos seus romances mais célebres. Publicado entre 1736 e 1738, o romance de memórias intitulado Les Égarements du cœur et de l'esprit ou Mémoires de M. de Meilcour, constitui, ainda hoje, a sua obra mais conhecida. Pela mesma altura, e na esteira de Tanzaï e Néaderné, Crébillon inicia a redacção de $L e$ Sopha, conte moral. A obra só será publicada em 1742, vindo a transformar-se num enorme e duradouro sucesso junto do público leitor, mas não tendo tido a mesma ventura junto dos censores, que condenam o autor a uma severa pena de exílio de Paris, como castigo pela reincidência nos crimes de lesa-majestade e de atentado à instituição religiosa, à moral e aos bons costumes. É provável que, no período acima referido, Crébillon tenha ainda redigido uma primeira versão dos seus dois diálogos intitulados La Nuit et le Moment, ou les matines de Cythère, dialogue (publicado apenas em 1755) e Le Hasard du coin du feu, dialogue moral, cuja publicação é adiada até 1763. Em 1754, surgem Les Heureux Orphelins, histoire imitée de l'Anglais e as primeiras sete partes de Ah quel Conte! Conte politique et astronomique, obra concluída em 1754. Em 1768, Crébillon publica a sua segunda monódia epistolar, Lettres de La Duchesse de ${ }^{* * *}$ au Duc de ${ }^{* * *}$, desta feita para problematizar tanto esta forma literária como o excesso de pormenores "realistas" sobre o modo de vida da classe burguesa presentes no romance sentimental inglês, muito particularmente na Pamela e na Clarissa de Samuel Richardson, que, juntamente com a influência de Julie, ou La Nouvelle Héloïse de Rousseau, tinham, entretanto, vindo a conquistar um enorme sucesso junto do público francês desde o início da segunda metade do século. Em 1771, Crébillon dá à estampa o seu último romance intitulado Lettres athéniennes, extraites $d u$ portefeuille d'Alcibiade, no qual procura explorar as potencialidades da polifonia epistolar, uma das fórmulas mais na moda depois dos sucessos acima referidos de Richardson e Rousseau, e antes de Laclos, seu admirador (cf. Versini, 1968). Embora o título prometa transportar o leitor até ao Século de Péricles, essa viagem filosófica no tempo e no espaço é, sobretudo, um pretexto para que o romancista proceda, uma vez mais, ao desmascaramento do sistema da libertinagem da corte francesa da época da Regência e do reinado de Luís XV.

A temática central da obra de Crébillon gravita, pois, em torno da análise do "cœur humain". Deste modo, paixão, galanteria e libertinagem são aí problematizadas, de uma forma lúcida e irónica tanto quanto distanciada e lúdica, como jogos de sedução e de dominação realizados com recurso a jogos discursivos fortemente retoricizados. Conhecido no seu tempo como o "físico do amor" ou "filósofo das mulheres", Crébillon é, sobretudo, um mestre do romance pela ironia da sua acuidade analítica, cuja minúcia incide sobre as múltiplas máscaras de Eros, desmistificando-as. Quer isto dizer que o autor se diverte, ao mesmo tempo que convida o seu leitor a com ele também se divertir, a desmontar os móbiles escondidos, as contradições e os álibis da concepção do amor depurado, herdada 
das "Précieuses" do século anterior, concepção essa votada, no entanto, ao fracasso no novo microcosmo aristocrático, dominado pelo império da galanteria e da libertinagem, aspectos essenciais no Sopha e em Ah quel Conte!.

Por outro lado, ao desmascaramento irónico do artifício da retórica da sedução, com os seus diversos jogos estratégicos e tácticos de uma requintada esgrima argumentativa e linguística, aliam-se quer uma estética do contraponto, quer uma poética da indecidibilidade do sentido. Estes processos permitem à instância autoral o simulacro da recusa de qualquer emissão de juízos de valor em nome próprio, delegando-os antes noutras instâncias textuais conflituosas, num jogo de vozes contrárias e contraditórias, de que são exemplo os narratários intradiegéticos do Sopha e Ah quel Conte!, jogo esse que apela à responsabilização hermenêutica do leitor. Este tem de se mostrar arguto e cúmplice, capaz de levantar o véu da decência linguística para fruir, não tanto o prazer encenado, mas antes o prazer da escrita literária sugestiva. O subtil trabalho da alusão convida, pois, a uma leitura astuta, que valorize a enunciação em detrimento do enunciado. Para além, portanto, da mestria analítica da multiplicidade dos jogos de sedução amorosa, a originalidade do projecto de escrita crébilloniano reside no modo como essa análise se entrelaça graciosamente com um espírito lúdico de puro divertimento, com o experimentalismo técnico-compositivo e com a problematização arguta das convenções poéticas e retóricas do seu tempo. Tal atitude leva o autor a questionar o romance enquanto género literário emergente, objecto de uma profunda transformação em curso, que pretende, contra tudo e contra todos, afirmar-se perante os géneros consagrados pela tradição literária e cultural da Academia francesa, vigentes ainda no contexto setecentista, marcado pelo racionalismo aristotélico-horaciano e pelo princípio estético da imitação. Assim, ao invés de um escritor frívolo e licencioso, às vezes bastante extravagante, estamos antes face a alguém que vê na literatura um objecto de prazer e que faz do jogo literário um jogo de sedução com o seu leitor, provocando-o e simulando delegar-lhe o poder interpretativo, quando, na verdade, o manipula, como fazem, aliás, todos os autores, apesar do que possam afirmar.

Esse jogo com o leitor funda-se, como já referimos, na ironia da poética da indecidibilidade do sentido e da estética do contraponto, sendo lançado logo a partir dos títulos das obras, passando, em seguida, nos casos em que isso se verifica, pelos vários elementos paratextuais, ou seja, as dedicatórias, as epígrafes, as notas de rodapé, os títulos internos e as instâncias prefaciais. No entanto, o referido jogo pode assumir igualmente outras formas de representação textual, tais como as do debate-comentário metanarrativo travado entre locutores e auditores intradiegéticos (nos contos orientais: Tanzaï et Néadarné, Sopha e Ah, quel conte!), ou a das intrusões da voz autoral, mascarada ou não de instância editorial, que interpela o leitor (no "Avis au Lecteur", nas Lettres de la Duchesse, assim como nos dois diálogos La Nuit et le Moment e Le Hasard du coin du feu). 
Com o seu espírito investigador e experimentalista, Crébillon tenta ainda explorar todas as potencialidades de um estilo frásico "entortillé", isto é, sinuoso e velado, que sublinha, paradoxal e ironicamente, aquilo que pretende esconder, apelando, com subtil malícia, à imaginação e à responsabilização do leitor pela interpretação erótica dos eventos narrados, o que desespera Schah-Baham e encanta a Sultana. Para tal, recorre abundantemente a figuras como a alusão, a elipse, a lítotes, a hipérbole, o eufemismo ou a perífrase. Deste modo, o romancista joga também com a hipocrisia do jargão galante, tão característico das suas personagens, desmascarando-o como puro jogo retórico, por um lado, mas, por outro, fazendo sua a alusão eufemística que lhe permite dizer o indizível, ao mesmo tempo que se distancia pela análise inteligente, minuciosa e irónica. Este jogo duplamente auto-irónico da voz autoral, que lucidamente se distancia tanto das suas personagens como da própria obra, completa-se com a ironia que se abate sobre a relação que é estabelecida com o seu leitor. O aparente inacabamento de muitas das obras crébillonianas, tão frequentemente criticado com alguma ligeireza, deverá antes ser interpretado como apenas mais uma das tácticas deste jogo estratégico, que, no final, reenvia o leitor para o início do texto, numa necessária releitura circular, a qual não pode deixar de evocar, na memória literária de um leitor do presente, a estratégia do romance proustiano (cf. Carvalho, 2003).

Ao encetar a leitura de uma obra intitulada Le Sopha, conte moral, as expectativas do leitor prevêem, com a legitimidade fornecida pelas convenções do género, um conto perfumado de erotismo e de exotismo maravilhoso. Supostamente publicado "A Gaznah, De I'Imprimerie du Très-Pieux, Très-Clément \& Très-Auguste Sultan des Indes. L'An de l'Hegire M.C.XX" (Crébillon, 2000: 735), o título - Le Sopha - designa um objecto de mobiliário com fortes conotações eróticas, aguçando a curiosidade libidinal do leitor; depois, o subtítulo, composto por uma indicação genológica - conte moral -, introduz-nos no universo feérico do conto, mas com uma ambiguidade decorrente do adjectivo "moral", que pode ser lido de forma neutra, como "relativo aos costumes" (mores), ou insinuando um juízo crítico severo dos maus costumes representados no texto. A justaposição do título e do subtítulo sublinha, com fina ironia, o contraste assim sugerido (comprovado ao longo da narrativa), convidando o leitor a entrar no jogo de duplicidades e de contraponto enunciados.

Contudo, ao folhear o texto, o leitor ficará certamente desconcertado, pois o jogo irónico da instância autoral manifesta-se desde logo nos títulos internos. Assim, no primeiro capítulo da Primeira Parte, pode ler-se: "Le moins ennuyeux du livre". Os seguintes fazem alternar a pseudo-depreciação com a provocação da curiosidade pela proposta de um enigma que seduz para a leitura: "Qui ne plaira pas à tout le monde"; "Qui contient des faits peu vraisemblables"; "Où l'on verra des choses qu'il se pourrait bien qu'on n'eût pas prévues"; "Meilleur à passer qu'à lire"; "Pas plus extraordinaire qu'amusant"; "Où l'on trouvera beaucoup à reprendre"; "Où l'on trouvera une grande question à décider"; "Où, 
entre autres choses, on trouvera la façon de tuer le temps"; "Qui contient une Recette contre les Enchantements". Na Segunda Parte temos: "Le même à peu près que le précédent"; "Fin d'une aventure, et commencement d'une autre"; "Qui contient moins de faits que de discours"; "Qui n'amusera pas ceux que les précédents ont ennuyés"; "Qui contient une Dissertation qui ne sera pas goûtée de tout le monde"; "Qui apprendra aux femmes novices, s'il en est, à éluder les questions embarrassantes"; "Rempli d'allusions fort difficiles à trouver"; "Ah! tant mieux!"; "Amusements de l'âme"”. Como nota A. Giard, "si la dépréciation feinte est une tactique qui vise à aiguiser le désir de savoir du lecteur, la déception concertée l'aiguille vers un savoir désirable" (Giard, 1986: 22-23), ou seja, a instância autoral convida o leitor a passar do primeiro para o segundo nível de leitura, do prazer da história para o prazer do discurso, pois incentiva a curiosidade mas fornece as informações de forma velada.

Trata-se, com efeito, de um conto moral, ou melhor, de uma recolha de conversas apresentadas por um narrador intradiegético, Amanzei, presentemente um cortesão do Sultão das Índias, mas que, no passado, teria visto a sua alma condenada a errar de sofá em sofá (!) até que dois amantes virgens a libertassem desta punição divina devida à sua libertinagem. A extravagância desta metempsicose, motivo tradicional do conto maravilhoso oriental, é usada por Crébillon para valorizar a estrutura da narrativa libertina. Para isso, o autor adapta-a aos seus fins, conjugando-a com o topos do voyeurismo, dado que Amanzei se recorda de tudo o que presenciou e é capaz de o narrar ao mais ínfimo pormenor. $A$ narração da sua desventura mostra que a personagem fútil se transformou interiormente pela observação dos desregramentos amorosos, mas também de alguns bons exemplos, dos seus contemporâneos, o que leva à reflexão moral. O maravilhoso constitui aqui um pretexto para a análise da casuística amorosa preciosa, servida pela subtileza refinada das perífrases que caracterizam o estilo "entortillé", tanto de Amanzei como de Crébillon.

Em Ah quel Conte! Conte politique et astronomique, a extravagância do título é desconcertante, sobretudo de acordo com as convenções da época ${ }^{5}$. A exclamação inicial terá um sentido positivo ou negativo? Se o leitor optar por seguir o topos da modéstia autoral, deverá, eventualmente, ter em conta a hipótese de o título ser auto-irónico, simulando a desvalorização do próprio texto como forma de antecipar as previsíveis críticas, uma vez que a exclamação, por um lado, sugere o carácter patranheiro dos contos numa

\footnotetext{
${ }^{4}$ Dois capítulos não ostentam título: o VIII, que introduz a sedução dos dois devotos, Almaïde e Moclès, desenvolvida no capítulo IX - "Où l'on trouvera une grande question à décider", a saber, qual dos dois mentiu quanto à sua virgindade, e que ficará ironicamente sem resposta, cabendo ao leitor decidir perante o que lhe é apresentado e de acordo com a sua própria experiência. A ausência de título no capítulo VIII poderá sugerir que o importante foi transferido para o seguinte, ou seja, a sedução pela retórica sofística de Moclès e a indecidibilidade final. O "CHAPITRE DERNIER" também não tem título. Ele corresponde à sedução mútua dos dois jovens apaixonados, Zéïnis e Phéléas, a qual obedece, enfim, aos requisitos de Brama, libertando, assim, a alma de Amanzei da sua prisão em sofás, concluindo logicamente a narrativa.

${ }^{5}$ Cf. Jomand-Baudry (1996: 105-109).
} 
perspectiva depreciativa e, por outro, prepara o leitor para a suprema extravagância da louca narrativa metamórfica atribuída ao Vizir Moslem ${ }^{6}$. Por contraponto, o subtítulo, ao indicar o género - "Conte" -, adjectiva-o de "politique et astronomique", ou seja, parece conferir-lhe uma certa seriedade, na linha dos contos filosóficos em voga. A provocação ao leitor é clara, e a expectativa deste não será defraudada. Como nota J. Dagen, "il ressort de la lecture de ce livre fou que les fictions les moins crédibles suscitent tout autant que d'autres, d'apparence plus rassurante, de judicieuses et profitables réflexions sur le cours des passions, sur les voies de la pensée scientifique, sur les spéculations politiques" (Dagen, 1995: 39; ver também, a este propósito, Cazenobe, 1997: 111-142).

Do ponto de vista técnico-compositivo, este livro extravagante - cujos capítulos, por contraponto ao Sopha, não apresentam títulos - afasta-se da convenção mimética aristotélico-horaciana, revelando-se profundamente experimentalista ao combinar, por um lado, os sucessivos encaixes narrativos; por outro, a mistura complexa de géneros, tradições e formas de escrita ${ }^{7}$, o que possibilita a problematização dos géneros literários tão cara a Crébillon. Por outro lado ainda, a diegese é contada quatro ou cinco vezes sob formas diferentes (narração de Moslem; a confidência mal-intencionada de Taciturne; o discurso político do "Grand Raisonneur"; a romança e os versos de Taciturne). Esta mise en abyme paródica ${ }^{8}$ conduz à questionação reiterada dos próprios limites da narrativa e da sua capacidade de transformação, da incessante reinvenção pela escrita:

Ces répétitions détournent le lecteur de l'histoire, l'en distancient pour attirer son attention sur le style en exercice, sur la prouesse formelle. Du même coup, la poétique du conte se déplace, et avec elle le plaisir du lecteur qui goûte l'humour produit par les variations et les effets d'échos. Ce ne sont plus le scénario et sa résolution qui importent, mais le seul mouvement réflexif de l'écriture et ses cristallisations en anamorphoses successives. Ce n'est pas ce que renvoie le miroir qui compte, mais les déformations qu'il engendre (Jomand-Baudry, 2002: 93).

\footnotetext{
${ }^{6}$ Recorde-se o início do Sopha, quando o Vizir (é verosímil que se trate de Moslem) afirma: "Sire [...], je puis assurer Votre Majesté, que non seulement j'en sais [des contes], mais que j'ai même le talent d'en faire de si bizarres, que ceux de feu Madame votre grand-mère [Schéhérazade] n'ont rien qui les puisse surpasser" (Crébillon, 2000: 286).

7 Cf. Jomand-Baudry (2002).

${ }^{8}$ Considerando Ah quel Conte! $(A Q C)$ como a continuação do Sopha (So), temos, num primeiro nível narrativo, um narrador extra e heterodiegético responsável pela Introdução ao Sopha e que põe em cena três personagens de cada vez, intervindo para comentar a sua inter-relação: o Sultão e a Sultana, auditores dos contos fabulosos de Amanzei (So) e de Moslem $(A Q C)$. Estes tornam-se, então, narradores intradiegéticos ou de segundo nível (homodiegético, no caso de Amanzei que testemunha - como sofá - as histórias que conta; heterodiegético, no caso de Moslem). Num terceiro nível, hipodiegético, as personagens dos contos de Amanzei e de Moslem narram a sua própria história (Zulica, no Sopha; o Rei Avestruz e a Rainha das Ilhas de Cristal, em AQC narradores autodiegéticos, interrompidos também eles pelos seus respectivos interlocutores: Nassès, Schézaddin e Taciturne). Mas em Ah quel Conte a complexificação narrativa agudiza-se com a incorporação de cartas entre Schézaddin e Manzaïde; peças de oratória política; uma romança (canção ou Pont-Neuf), que constitui uma das mise en abyme paródicas de todo o conto-romance, tal como uns "beaux couplets", sobre a paixão do príncipe pela princesa-gansa, peças poéticas da autoria de Taciturne (Crébillon, 2001).
} 
Mas qual é, então, esta história assim tão extravagante? Primeiro, são-nos narradas, com toda a minúcia da análise sentimental própria de Crébillon, as aventuras e desventuras amorosas de Schézaddin e da fada Tout-ou-rien ${ }^{9}$. Esta possui todos os poderes sobrenaturais de uma fada acrescidos do poder de sedução da mulher libertina e, após uma ruptura azeda com o príncipe, condena-o a um terrível coup de foudre, cujo objecto será ridiculamente $^{10}$ uma gansa, que Schézaddin, contudo, acredita ser a princesa Manzaïde, metamorfoseada devido a um encantamento de que tinham sido alvos o Rei seu pai e toda a Corte. Vejamos agora um dos resumos possíveis da continuação desta extravagância feérica, na variante do discurso político proferido por Quamobrem, o "Grand Raisonneur", perante os Senadores e membros da Câmara dos Comuns ${ }^{11}$ :

J'ose vous répondre que quelque étonnants que puissent être les Contes que vous avez lus, il ne vous en est jamais tombé entre les mains, d'aussi extraordinaire, et j'ose même ajouter, de si absurde, puisque tout Conte doit l'être plus au moins, que l'histoire que j'ai à vous raconter aujourd'hui. D'abord, c'est un Roi, si grand Physicien de sa profession, que c'est à lui que nous devons l'invention des cerfs-volants, Génie, d'ailleurs, on le voit bien, à qui, non seulement sans aucun droit, mais encore contre toute raison, on vient insolemment demander un plat à barbe qu'il chérissait plus que sa vie, et qui lui venant en droiture du Destin (personnage, par parenthèse, que nous ne croyons pas s'être jamais fait raser) a acquis pour prix de ses services, le précieux don de prophétie. Ce Roi, vaincu par une Tête à Perruque (ayez, je vous prie, la bonté de suivre ceci), dépouillé tout à la fois, par les malheurs de la guerre, de son plat à barbe et de ses États, pris même dans une ratière, est encore, pour comble de maux, transformé en Autruche par son adversaire, Génie comme lui, ainsi que vous le voyez, mais beaucoup plus puissant [...]; et que non seulement lui, la Reine sa femme et toute sa Cour sont Autruches: mais encore que cette punition s'étend sur Mademoiselle sa fille, qui est Oison, sur son propre neveu [...], dont on a fait un Dindon; sur sa cousine, Princesse d'un rare mérite, qui, pour cela, n'en est pas moins Grue, et sur tous leurs sujets [...]. Mais ce qui va, sans doute, vous faire trembler pour eux, c'est que ce Roi, sa femme, sa fille, ses parents, ses peuples doivent rester sous ces formes ridicules, jusques à ce qu'il se trouve un Prince qui prenne assez de goût pour l'infortunée Princesse, dont on a fait une Oie, pour consentir à l'épouser [...] (Crébillon, 2001: 608).

\footnotetext{
${ }_{10}^{9}$ Alegorias do jovem Luís XV e, talvez, de Mme de Mailly.

${ }^{10} \mathrm{O}$ ridículo do objecto amoroso problematiza a crença no coup de foudre enviado pelo Destino e na exclusividade amorosa.

${ }^{11} \mathrm{O}$ recurso ao sistema político inglês tanto pode ser lido como tentativa de manobra escapatória à censura francesa como crítica velada a uma forma de governo defendida por alguns dos mais importantes filósofos franceses.
} 
O auditório de Quamobrem reage de forma indignada perante tal conto qualificado como o mais "ridicule", "déplacé", "impertinent", "inepte", "fade", "indécent", "absurde", etc. jamais inventado (Crébillon, 2001: 609-610). Porém, a questão é mais delicada quando se aplicam as "chaves" interpretativas: trata-se aqui da guerra da Sucessão da Polónia, da humilhação do rei Estanislau I Leszczyński e, pior ainda, do casamento da filha deste, Maria, com Luís XV - daí o conto político. Quanto à Astronomia, o rei polaco passava por ser um entusiasta das novas disciplinas científicas. Contudo, o conto tanto parodia os topoï do romance sentimental e de cavalaria (relação Schézaddin - Tout-ou-rien, a cena do coup de foudre, auto-retrato de Manzaïde, cenas de escuta indiscreta, combate singular, etc.), como os do conto maravilhoso (riquezas hiperbólicas, metamorfoses, amores monstruosos), como ainda satiriza o discurso científico, confrontando maravilhoso e ciência (cf. Jomand-Baudry, 2002).

Os títulos dos capítulos do Sopha corroboram o programa de leitura proposto na "INTRODUCTION" (o qual é transposto para o nível intradiegético, sob a forma do debate, nos comentários dos dois auditores dos contos de Amanzei - o Sultão e a Sultana, alegorias dos leitores de primeiro e de segundo nível, respectivamente, como veremos adiante). Assim, esta Introdução, misto de prefácio e de início da narrativa, acentua o jogo retórico entre autor e leitor, no qual se cria um distanciamento irónico que visa, de forma aparentemente paradoxal - e sentida como extravagante -, valorizar o texto que se apresenta e, com isso, seduzir o leitor, ainda que pela provocação desconcertante. Temos, então, aquilo a que Genette chama um prefácio autoral mascarado (Genette, 1987), no qual um locutor anónimo se dirige a um alocutário também ele anónimo e colectivo, dando-se início a uma narrativa que assenta numa táctica do equívoco entre a crítica de costumes de tom mais realista e a ficção feérica provocatoriamente extravagante:

II y a déjà quelques siècles qu'un prince nommé Schah-Baham régnait sur les Indes. II était petit-fils de ce magnanime Schah-Riar, de qui l'on a lu les grandes actions dans Les Mille et une nuits, et qui, entre autres choses, se plaisait tant à étrangler des femmes, et à entendre des Contes: celui-là même qui ne fit grâce à l'incomparable Schéhérazade, qu'en faveur de toutes les belles histoires qu'elle savait (Crébillon, 2000: 281).

Este incipit coloca algumas questões interessantes. Um diálogo desenha-se aqui entre a instância autoral (mascarada sob a figura de um transcritor, ou mesmo tradutor, anónimo de uma fonte antiga, supostamente autêntica) e o seu destinatário, contemporâneo e cúmplice na apreciação de um texto célebre em França desde o início do século XVIII, as Mil e Uma Noites, na tradução de Galland. Estabelece-se, então, um jogo de temporalidades 
e, implicitamente, de espaços: o locutor que fala aqui e agora dirige-se a um alocutário anónimo, contemporâneo e, com toda a probabilidade, compatriota, ou seja, trata-se do equivalente às categorias de autor e de leitor. Aquilo de que se fala, o delocutivo, refere-se à história de um príncipe reinante nas Índias (ou seja, um local geograficamente exótico em relação ao aqui da enunciação), em tempos longínquos - alguns séculos atrás -, relativamente ao agora. Porém, o príncipe, chamado Schah-Baham, é apresentado como neto dos lendários protagonistas das Mil e Uma Noites: Schah-Riar e Schéhérazade. O leitor é, assim, convidado a entrar no universo fabuloso dos contos orientais em voga. No entanto, a admiração pela narrativa citada é, desde logo, problematizada pela ironia apreciativa das personagens: as "grandes actions" do "magnanime Schah-Riar" não passam, afinal, dos extravagantes prazeres de "étrangler des femmes" e "entendre des Contes", tendo sido este último aspecto a salvação da "incomparable Schéhérazade". Assim, este texto liminar cumpre a função de instância prefacial, propondo um programa de leitura e procurando seduzir os vários tipos de leitores (através da captatio benevolentiae - "on a lu"): quer aqueles que esperam uma "continuação" das Mil e Uma Noites (e que serão defraudados), quer aqueles que, aceitando a provocação de uma escrita inovadora, se deixam encantar com a desmontagem irónica dos códigos estabelecidos. De facto, Schah-Baham é apresentado, em seguida, por esta voz heterodiegética como pouco perspicaz e apaixonado pelos contos da sua avó (alegoria de uma literatura antiga e caduca):

Soit que Schah-Baham ne fût pas extrêmement délicat sur I'honneur, soit que ses femmes ne couchassent point avec leurs nègres, ou (ce qui est, pour le moins, aussi vraisemblable) qu'il n'en sût rien, il était bon et commode mari, et n'avait hérité de Schah-Riar que de ses vertus, et de son goût pour les Contes. On assure même que le Recueil des Contes de Schéhérazade, que son auguste grand-père avait fait écrire en lettres d'or, était le seul livre qu'il eût jamais daigné lire (Crébillon, 2000: 281-282).

Atente-se na crébilloniana poética da indecidibilidade do sentido manifestada pela construção alternativa ("soit que [...], soit que [...]; ou [...] qu'il [...]"), da qual resulta, contudo, pela observação contida no parêntesis, a sugestão de que a última hipótese seja talvez a mais provável. Deste modo, acentua-se subtilmente a estupidez da personagem (reiterada ao longo de todo o romance, assim como a sua infantilidade), o que ironiza o seu gosto pelos contos fabulosos narrados nas Mil e Uma Noites. Schah-Baham é aqui uma alegoria do leitor ingénuo e acrítico que, sistematicamente, se equivoca na interpretação dos factos narrados e dos caracteres das personagens, devido quer à sua natural falta de perspicácia, quer ao seu único e precipitado interesse pela sucessão dos acontecimentos e pelo desfecho das histórias, desprezando o modo como elas são postas em discurso. 
Por outro lado, o locutor desta Introdução distancia-se já, com subtileza e algum equívoco, quanto à autoria da narrativa que apresenta, ao afirmar que "on assure même [...]". Este "on" revela uma ambiguidade autoral, tornando indeterminada a fonte responsável pela certificação daquilo que é afirmado. Mais adiante, ela será nomeada, mas apenas para reforçar o jogo irónico de problematização da convenção das fontes autênticas e fidedignas.

O locutor aproveita a sua última afirmação para introduzir uma digressão metaliterária sobre a forma do conto, fazendo a sua apologia, pois os contos ornam o espírito e encerram conhecimentos e ideias agradáveis e sublimes, mas afirmando igualmente que é perigoso não ler outras espécies de livros, pelo menos para os leitores pouco esclarecidos e sujeitos a preconceitos:

À quelque point que les Contes ornent l'esprit, et quelque agréables, ou quelque sublimes que soient les connaissances et les idées qu'on y puise, il est dangereux de ne lire que des livres de cette espèce. II n'y a que les personnes vraiment éclairées, audessus des préjugés, et qui connaissent le vide des Sciences, qui sachent combien ces sortes d'ouvrages sont utiles à la société, et combien l'on doit d'estime, et même de vénération aux gens qui ont assez de génie pour en faire, et assez de force dans l'esprit pour s'y dévouer, malgré l'idée de frivolité que l'orgueil et l'ignorance ont attachée à ce genre. Les importantes leçons que les contes renferment, les grands traits d'imagination qu'on y rencontre si fréquemment, et les idées riantes dont ils sont toujours remplis, ne prennent rien sur le vulgaire, de qui l'on ne peut acquérir l'estime qu'en lui donnant des choses qu'il n'entend jamais, mais qu'il puisse se faire honneur d'entendre (Crébillon, 2000: 282).

Esta apologia, enquanto definição genológica, é, no entanto, equívoca. Por um lado, como nota $\mathrm{C}$. Dornier, ela "prend une valeur ironique dans la mesure où c'est le personnage de Schah-Baham, souvent ridiculisé dans la suite du Sopha, qui apparaît comme un exemple de 'ces personnes vraiment éclairées' qui aiment les contes" (Dornier, 1994: 146). Por outro, contudo, a instância autoral procura persuadir o leitor perspicaz do valor dos contos, nomeadamente do(s) seu(s) ${ }^{12}$, jogando com o topos da utilidade moral aliada ao prazer estético e à instrução (o trio das finalidades retóricas de mouere, docere e delectare). Desta forma, como afirma Régine Jomand-Baudry:

Le conte à la manière de Crébillon n'est pas un récit simple, et pas seulement à cause de sa complexité diégétique et de l'emboîtement de la structure narrative. Sur le plan de la poétique, il se situe au croisement de différents genres ou de différentes traditions,

\footnotetext{
12 Podemos considerar que esta Introdução tanto pode servir ao Sopha como a Ah quel Conte!, dado que as personagens do Sultão e da sua esposa asseguram a continuidade entre os dois textos.
} 
dont il fait éclater les codes. Les analyses [psychologiques] du roman galant sont curieusement mêlées aux ressorts conventionnels du conte, sans qu'elles ne perdent rien de leur validité. Crébillon ne prend ses distances avec la mécanique narrative du conte orientalisant que pour réinsérer un pittoresque oriental de surface. En outre, sa forte dimension réflexive, à travers la parodie, l'auto-ironie et le jeu des instances de narration et de réception en fait une œuvre critique et auto-critique, qui réinterprète la littérature antérieure et se met sans cesse en question. Le conte se définit alors comme un genre ouvert et accueillant où s'exerce ludiquement l'écriture. II n'est pas étonnant que l'articulation de ces différents horizons lui donne une tonalité étrange, parfois loufoque (Jomand-Baudry, 2002: 100).

Na Introdução do Sopha define-se, então, um programa de leitura que distingue, com fina ironia, dois tipos de leitores: o ingénuo e apressado, alegorizado pelo ignorante e extravagante Schah-Baham ${ }^{13}$; o arguto e apreciador da efabulação discursiva, alegorizado, talvez com subtil intencionalidade valorativa, pela personagem feminina da Sultana. O jogo irónico intensifica-se, pois esta auditora arguta começa por pôr em causa o valor dos contos. Ao contrário do marido, ela é inteligente, qualidade rara num meio tão frívolo e extravagante (Crébillon, 2000: 284). Descrição, narração e comentário autoral entrecruzam-se, mantendose, de certa forma, a incerteza quanto à instância enunciadora responsável, a "fonte antiga" ou o locutor anónimo, autor da Introdução.

Os comentários metanarrativos actorais, enquanto tipo de paratexto, instituem o jogo irónico de sedução, provocação e poder proposto como programa de leitura pela instância autoral, mas de forma delegada, ao problematizarem as convenções romanescas a partir do interior da narrativa, interrompendo-a para a comentar, para orientar ou desorientar o leitor com hipóteses interpretativas contraditórias ou falsas, para debater o interesse, a moralidade e a verosimilhança da história e o valor do modo de a contar. Crébillon ensaiara já em Tanzaï et Néadarné ${ }^{14}$ o recurso aos comentários dialogados sobre a narrativa da responsabilidade das personagens, isto é, incorporados na diegese e assumindo a forma do debate, recurso esse que será amplamente explorado no Sopha e em Ah quel Conte! e que realça o relativismo das convenções literárias e dos juízos críticos sobre as obras. Através da mise en abyme lúdica e irónica dos seus romances, o autor parodia-os e valoriza-os simultaneamente. Assim, a colocação de Schah-Baham e da Sultana em acção e em diálogo acentua as diferenças intelectuais entre ambos (cf. Crébillon, 2000: 285-286). Com

\footnotetext{
${ }^{13}$ Cf. Crébillon (2000: 282-284).

${ }^{14}$ É na edição de Londres de 1735 que o romance surge com o título: L'Ecumoire, Histoire japonoise. A carga simbólica do termo é múltipla: político-religiosa (a bula Unigenitus), erótica (o poder da virilidade, ou a falta dele) e até literária, ou seja, o poder autoral e/ou, simultaneamente, o convite ao leitor para "escumar", para filtrar ou decantar a "espuma" do sentido, a subtileza irónica da escrita crébilloniana. Esta "história japonesa", contudo, é supostamente editada "A PEKIN, Chez LOU-CHOU-CHU-LA, Seul Imprimeur de Sa Majesté Chinoise pour les langues étrangéres" (Crébillon, 1999: 567), confusão geográfica paródica explicada (?) pelo pretenso tradutor francês no Prefácio.
} 
efeito, a Sultana critica os contos com tal veemência, que se institui no texto um contraponto irónico em relação à apologia anterior. Para ela, trata-se de obras pueris e frívolas, absurdas e inverosímeis, ridículas e extravagantes, fábulas miseráveis que corrompem o espírito e os sentimentos (cf. nossa epígrafe). A argumentação da Sultana ${ }^{15}$ funda-se nas críticas à inverosimilhança e à imoralidade dos contos, e do romance em geral, veiculadas pelos teorizadores literários e pelos moralistas coevos. Este contraponto é um dos traços mais significativos da poética crébilloniana, que joga, assim, com discursos contraditórios, simulando dar uma liberdade de escolha ao leitor e colocar sob suspeita a sua própria obra, mas apenas estrategicamente para melhor a valorizar, enquanto critica os preconceitos estéticos e morais contra o romance.

Assim, ao mesmo tempo que a instância autoral faz o seu auto-elogio irónico e velado, o leitor de Le Sopha e Ah quel Conte!, vítima constante de falsas pistas e de enunciados contraditórios e extravagantes, é convidado a aguçar a sua desconfiança, a sua perspicácia e o seu espírito crítico. Colocadas em cena nos dois contos-romances, as personagens dos dois auditores relacionam-se de forma diferente com os dois narradores intradiegéticos. Os contos de Amanzei merecem, pelo seu modo de enunciação, a cumplicidade da leitora fina e a constante censura do leitor apressado e interessado apenas nos pormenores eróticos, que Ihe são ou negados ou subtilmente velados num discurso alusivo. Contudo, neste caso, a maior extravagância do texto reside no recurso ao estratagema da metempsicose, que permite ao narrador intradiegético assumir, com verosimilhança (!), uma posição privilegiada na observação dos comportamentos íntimos dos seus contemporâneos, visto que a sua alma fora condenada a permanecer enclausurada em sofás até que "deux personnes se donneraient mutuellement, et sur [lui], leurs prémices" (Crébillon, 2000: 293). Deste modo, o sobrenatural enquadra o mundo normal: as relações amorosas são secretamente presenciadas pela alma de Amanzei enquanto sofá. Mas a sua libertação e consequente assunção da forma humana são condições indispensáveis para a existência de tal narrativa, fazendo com que o sobrenatural e o realismo das cenas eróticas surjam entrelaçados, permitindo a análise psicológica e de costumes, tanto mais que a condição imposta para a libertação redentora de Amanzei tarda em produzir-se. Porém, novo paradoxo crébilloniano, quando ela se verifica, Amanzei sofre profundamente com o que tanto havia almejado, porque entretanto se apaixonara pela jovem que o deverá salvar...

O segundo narrador, Moslem $(A Q C)$, apresenta um conto "político e astronómico" de tal modo extravagante que suscita logo ao início a impaciência da Sultana perante tamanha

\footnotetext{
${ }^{15}$ A reacção do Sultão é grave mas cómica, pois ele é incapaz de contra-argumentar ao mesmo nível (Crébillon, 2000: 287). Trata-se de um receptor fascinado justamente por tudo aquilo que a Sultana condena inverosimilhança demasiado extravagante e imoralidade, ou licenciosidade -, apoiado, no entanto, na autoridade da sua posição de tirano.
} 
inverosimilhança, mesmo para um conto, e a cómica cumplicidade do Sultão, o qual, embora pouco compreenda dos sentidos profundos daquilo que lhe é narrado, fica fascinado com os aspectos superficiais desta bizarria feérica. Os seus constantes disparates e erros interpretativos $^{16}$ chamam, contudo, num plano superior, a atenção do leitor perspicaz para as pistas falsas que são enganadoras e que ameaçam qualquer escolha interpretativa, sugerindo, assim, a preocupação da instância autoral em provocar a sua desconfiança e a sua perspicácia analítica e crítica, não apenas em relação às questões morais e psicológicas, mas quanto a uma reflexão teórica sobre o conto, seja ela apologética ou censuradora, iniciada logo na introdução do Sopha, como vimos.

Para além da problemática da inverosimilhança e da imoralidade dos conteúdos narrativos, as interrupções e os comentários de Schah-Baham e da Sultana questionam também os aspectos do ritmo da narração e do estilo discursivo dos contistas. No Sopha, as cenas eróticas surgem entremeadas de longas conversações e de judiciosas reflexões do narrador, que muito aborrecem o Sultão, ávido de pormenores picantes e ansioso pelo final das aventuras, ameaçando de morte os desobedientes ("Aurez-vous bientôt fait? interrompit le Sultan en colère. Ne voilà-t-il pas vos chiennes de réflexions qui reviennent encore sur le tapis?" - Crébillon, 2000: 300). Quando Amanzei responde que, em certas ocasiões, elas são indispensáveis, o Sultão replica:

Et moi, je prétends [...] que cela n'est pas vrai; et quand cela serait... En un mot, puisque c'est à moi qu'on fait des contes, j'entends qu'on les fasse à ma fantaisie. Divertissez-moi, et trêve s'il vous plaît, de toutes ces morales qui ne finissent point et me donnent la migraine. Vous aimez à faire le beau parleur: mais, parbleu, j'y mettrai bon ordre, et je jure, foi de Sultan, que je tuerai le premier qui osera me faire une réflexion. Nous verrons à présent comment vous vous en tirerez. / En me préservant des réflexions, répondit Amanzei, puisqu'elles n'ont pas le bonheur de plaire à Votre Majesté. Fort bien cela, dit le Sultan, allez (Crébillon, 2000: $300^{17}$ ).

Este exercício do poder autoritário do soberano sobre o súbdito alegoriza ironicamente a relação de poder do sistema comunicativo literário, quando a instância autoral finge submeter-se à vontade e ao gosto do leitor tirano, sendo que, na realidade, este se encontra à sua mercê. De facto, Amanzei, o delegado intradiegético da instância autoral, apesar da aparente submissão, continua com as suas reflexões, mostrando-se aos

\footnotetext{
${ }^{16}$ Cf. Sopha (Crébillon, 2000: 317; 350-352; 371; 419-420; 424, apenas a título de exemplo); e Ah quel Conte! (Crébillon, 2001: 314-315; 328-329; 426; 442-443; 474; 489-490; 511; 525-526; 533; 536; 584-585, por exemplo). 17 Cf. igualmente pp. 333; 344-345; 365; 374; 400-401 - onde a Sultana explica que uma dissertação pode ser útil quando corresponde a "un fait [...] dialogué" -; 405-406; 412; 418-419; 424 (fim do cap. XVI e início do seguinte); 429-430; 445 e 459). E em Ah quel Conte! também, naturalmente (Crébillon, 2001: 314-315; 383-384; $449 ; 450 ; 477 ; 480-481 ; 482 ; 604-605 ; 615 ; 616-617)$.
} 
olhos do amo como "un bavard, qui se mire dans tout ce qu'il dit, et qui [...] a le vice d'aimer les longues conversations, et de faire le bel esprit" (Crébillon, 2000: 401). Moslem, contudo, revela-se mais condescendente para com os desejos do Sultão, embora numa atitude hipócrita: "Moslem qui n'était pas assez heureux pour pouvoir dire tout haut ce qu'il pensait de la perpétuelle imbécillité de son auguste maître, se contenta d'en soupirer en lui-même" (Crébillon, 2001: 304) ${ }^{18}$.

As disputas entre os dois auditores encenam a reflexão autoral sobre o seu próprio fazer literário. Assim, pela boca da Sultana, o autor permite-se teorizar sobre o modo de suscitar o interesse narrativo, como quando, por exemplo, à pergunta de Schah-Baham, "mais pourquoi [...] dans une histoire, ou dans un conte, comme vous voudrez, tout n'est-il pas intéressant?", ela responde:

Par bien des raisons [...]; ce qui sert à amener un fait ne saurait, par exemple, être aussi intéressant que le fait même: d'ailleurs si les choses étaient toujours au même degré d'intérêt, elles lasseraient par la continuité; l'esprit ne peut pas toujours être attentif, le cœur ne pourrait soutenir d'être toujours ému, et il faut nécessairement à l'un et à l'autre des temps de repos (Crébillon, 2000: 383).

As duas razões apresentadas pela Sultana revelam um conhecimento dos códigos literários relativos à estrutura narrativa e às condições de persuasão do receptor. Estas considerações sobre o ritmo narrativo distinguem a leitora astuta do leitor ingénuo, cuja única preocupação consiste na alternância entre divertimento e aborrecimento, enquanto ela compreende a funcionalidade dos tempos fracos (catálises) na valorização dos fortes (funções cardinais) e, por consequência, no todo narrativo. Ao leitor apressado, contrapõese a leitora que sabe apreciar o valor durativo das reflexões e das conversas, ou seja, da enunciação e da narração. Elas são úteis e necessárias, pois constituem factos dialogados, ao contrário dos supérfluos propos de table preferidos pelo Sultão. O debate sobre a pertinência das reflexões judiciosas do narrador problematiza ironicamente a poética do autor, que finge atacar-se e defender-se a si próprio, jogando, através da auto-irrisão, com o leitor, ao qual simula conceder liberdade de escolha.

O jogo de depreciação dos contos complexifica-se quando atinge o nível hipodiegético: uma das personagens da narrativa de Moslem, Taciturne, emite o seguinte juízo:

\footnotetext{
${ }^{18}$ Este juízo refere-se à pretensão de Schah-Baham de que o conto de Moslem estaria "rempli de portraits" alusivos a personagens reais, o que, aliás, é verdade. Não obstante, parodia-se o gosto do público leitor pelas célebres "clés", condenado por Crébillon no prefácio dos Égarements.
} 
Que voudriez-vous faire d'un Conte? Un tissu de sottises et de platitudes est-il fait pour vous amuser? Ce n'est pas avec autant d'esprit que vous en avez, que l'on peut se plaire à de pareilles misères? Laissons à ces gens bornés, qui ne savent pas même tirer parti de leur oisiveté, à faire ou à entendre des Contes (Crébillon, 2001: 399).

O Sultão interrompe Moslem para acusar a sua personagem (Taciturne) de "insolence" e de "bêtise", proibindo-o de retomar um juízo quase tão ofensivo como um crime de lesa-majestade (op. cit:: 399-400). O narrador limita-se a satisfazer os desejos do seu Senhor, o verdadeiro alvo de todas as críticas, saindo, de certa forma, ilibado das acusações de extravagância e imoralidade do conto, mas não do tédio que provoca no auditório:

On dira ce qu'on voudra; mais c'est, ma foi! une belle chose qu'un Conte [diz o Sultão], surtout quand on y trouve, comme dans celui-ci, une morale épurée, de beaux préceptes, et je ne sais combien d'autres choses encore qui se sentent mieux qu'on ne peut les dire, et qui vous élèvent l'esprit, en même temps qu'elles l'amusent. C'est qu'il ne faut pas croire, non, qu'il soit donné à tout le monde, de réunir l'utile et l'agréable. Cela est bien vrai, dit la Sultane; pour le Vizir, on n'a rien à lui reprocher; s'il conte bien, il endort encore mieux (Crébillon, 2001: 388).

Algumas páginas adiante, esta subtil ironia da Sultana transforma-se numa explosão de impaciência: "[q]uel Conte! quel maussade Conte! quel indigne Conte! [...] Des Dindons jouer de la flûte! Passe encore pour parler: on en entend quelques-uns dans le monde; mais..." (op. cit.: 408). Apesar de tudo, a inverosimilhança extravagante deve, segundo ela, ter limites, mesmo num conto maravilhoso, ao contrário do que julga o Sultão, ou seja, deve respeitar as convenções do género:

C'est qu'il y a des choses qui sont si visiblement hors de la nature, que, quelque indulgent que l'on veuille être, elles ne peuvent pas avoir le droit d'amuser. Tels, par exemple, sont les Dindons que vous prenez si généreusement sous votre royale protection. Je n'ignore pas que le merveilleux le plus outré, les exagérations les plus puériles, les métamorphoses les plus absurdes, sont de l'essence du Conte; mais je sais aussi que, quelque bizarrerie qu'on lui permette, il faut, au moins, que les objets qu'il présente aient quelque chose d'agréable, et de piquant. II n'y a rien qui n'ait ses règles; et cette misère que l'on appelle un Conte, a les siennes, comme toute autre chose (Crébillon, 2001: 408). 
Crébillon coloca na boca da sua personagem espirituosa um ataque feroz à sua própria obra ${ }^{19}$. Parecendo defender as regras convencionadas e condenar os excessos inventivos, ele está, pelo contrário, a antecipar acusações, por um lado e, por outro, a sugerir que o verdadeiro valor do seu conto consiste, justamente, na problematização dos códigos e na inovação, como já o fizera com a exclamação de Schah-Baham no explicit do Sopha: "Ah! Ma grand-mère! [...] ce n'était pas ainsi que vous contiez!" (Crébillon, 2000: 459). Por sua vez, o Sultão elogia agora o narrador Moslem: "[c]ontinuez, Vizir, voilà véritablement une des plus magnifiques histoires que je crois qu'on puisse entendre" (Crébillon, 2001: 437). Ele não deixa de reconhecer a excessiva liberdade inventiva dos contistas $^{20}$. No entanto, ele próprio não é capaz de fugir a esse sortilégio, confundindo as aparentes extravagâncias pueris e frívolas de Moslem com acontecimentos grandiosos, sérios e inesperados ${ }^{21}$. A autodepreciação da instância autoral é, pois, simulada e irónica, convidando o leitor a ultrapassar o nível do prazer da história para atingir um nível mais profundo de sentidos velados, de crítica sociopolítica, bem como o do prazer do discurso ousado e inovador, pois este jogo de autodepreciação irónica envolve também uma mise en abyme da suposta extravagância estilística de Crébillon. O Sultão acusa os vários locutores de hermetismo pelo abuso de circunlocuções ininteligíveis, queixando-se do galimatias tanto de Amanzei (Crébillon, 2000: 293) como de Moslem (Crébillon, 2001: 314; 329). No entanto, aprecia a elegância do discurso entortillé da Rainha das Ilhas de Cristal (Crébillon, 2001: 516). Através da sua fina ironia, a instância autoral finge acusar o seu próprio estilo, antecipando as críticas do público. Na realidade, contudo, sugere-se ao leitor arguto e cúmplice uma orientação de leitura apreciativa inversa, valorizando a pertinência analítica e estética da retórica da alusão. Na verdade, o discurso crébilloniano apenas parece obscuro numa abordagem apressada e superficial, pois ele visa justamente o contrário, uma leitura lenta, atenta e minuciosa, feita de avanços e recuos sucessivos, leitura essa que o torna, afinal, cristalino. As críticas finais dos dois auditores, em ambos os contos-romances, mantendo a disputa, confirmam a ideia de autovalorização velada das obras, nas quais a

\footnotetext{
${ }^{19}$ A Sultana volta a impacientar-se violentamente mais adiante (Crébillon, 2001: 459). Por outro lado, ela considera a história encaixada da Rainha das Ilhas de Cristal "au moins fort inutile", uma vez que "ce n'est pas sur cette Grue, qui n'est par elle-même qu'un personnage épisodique, que roule l'intérêt, s'il y en a; [elle ne voit] pas à quoi peut servir son histoire, à moins que ce ne soit à allonger ce Conte" (Crébillon, 2001: 477). Naturalmente, o Sultão, que começara por repudiar tal narrativa, deseja agora ouvi-la, receando perder o melhor do conto.

${ }^{20}$ Cf.: "Vous croyez donc [...] que je ne sais pas ce que c'est qu'un Conte? Est-ce que l'on doit jamais s'y douter de quelque chose, à moins qu'on ne veuille être une dupe! Et ne faut-il pas être bien ignorant, pour ne pas savoir que tous ces maudits Conteurs ont la rage d'arranger les événements d'une autre façon souvent, que celle que vous aviez prévue" (Crébillon, 2001: 442-443).

${ }^{21}$ Cf.: "Il faut l'avouer; les événements de cette histoire sont grands, inattendus, donnent terriblement à penser; et voilà ce que j'aime; car, pour ces choses frivoles, dont, quand vous les avez lues, il ne vous reste rien dans la tête, et qui vous amusent simplement pour vous amuser; on m'en dira ce que l'on voudra, mais je donnerai toujours la préférence au sérieux. Le solide; il en faut toujours revenir là" (Crébillon, 2001: 453). No entanto, do ponto de vista da alegoria política, acaba por ter razão sem o saber.
} 
instância autoral, utilizando a autodepreciação com fina subtileza irónica, só finge questionar o seu fazer literário para melhor o defender ${ }^{22}$.

No caso específico dos dois textos que aqui nos ocupam, Crébillon parece bem ciente da importância cultural da extravagância do conto maravilhoso, mas, sobretudo, da necessidade de o adaptar aos novos tempos das Luzes. De facto, como afirma Carmen Ramirez:

Le conte au XVIIle siècle poursuit l'écriture du merveilleux, de ses représentations fabuleuses, qui mettent en récit la cérémonie prodigieuse du regard - certes d'un regard éclairé - portant essentiellement sur le monde et sur les autres et leur rapport à la raison et à la vérité. Le réalisme précieux, l'introspection, le roman d'analyse et les féeries de la Grandeur avaient favorisé l'esthétique baroque du leurre et le goût des fantaisies aimables. Progressivement, sans détourner les contes de leur badinage de salons, les conteurs vont s'interroger sur une société moderne, dont les valeurs éthiques et esthétiques en mutation allaient dans certains cas transformer le conte plaisant en une allégorie du savoir et du progrès de l'esprit humain, orientant le conte merveilleux vers le conte des Lumières [...], en l'engageant sur la voie de la pensée (Ramirez, 2002: 223).

Mais adiante, a autora precisa ainda que o conto maravilhoso, pautado por uma estética de valorização da moral e da verosimilhança, procurou desmascarar e ironizar os seculares logros, preconceitos e imposturas, através da análise da complexidade das relações entre seres humanos, maravilhoso e verdade. Assim, Crébillon encontra-se entre os autores que contribuíram para a modificação da natureza do maravilhoso feérico do conto, "mais ce fut à l'avantage des Lumières" (Ramirez, 2002: 224). E a autora conclui:

Le conte merveilleux, conte-laboratoire destiné à éprouver la raison et le vrai, se devait dorénavant de garantir le soupçon salutaire, de développer le doute cartésien, d'imposer le questionnement raisonnable, au travers d'une critique lucide et tranquille, d'une enquête intellectuelle inéluctable et plaisante, visant l'esprit, le cœur, et la raison infiniment interrogés par le conteur, tour à tour moraliste, historien et parfois même philosophe, tel le narrateur du conte moral de Crébillon [Le Sopha] (Ramirez, 2002: 224-225).

Em Crébillon coexistem, portanto, duas entidades, a do contista e a do moralista. Enquanto contista, dá largas à sua imaginação, recuperando e transformando um vasto fundo cultural onde se cruzam as diferentes tradições associadas ao maravilhoso, não

\footnotetext{
${ }^{22}$ Cf. Crébillon (2000: 459) e Crébillon (2001: 626-628 e 636-637).
} 
receando a mais louca extravagância, que, paradoxalmente, o coloca sob suspeita. Enquanto moralista, no entanto, como nota Carmen Ramirez, ele

ne renoncera pas à incorporer la peinture des mœurs à une vaste enquête intellectuelle, modulée par le dialogue, le scepticisme et l'ironie. Au triple palier poétique, intellectuel et heuristique, Crébillon conçoit le soupçon du merveilleux comme le besoin nécessaire de comprendre les mécanismes de l'esprit humain, trop enclin à l'illusion, et de maîtriser les clés morales et historiques de la société, trop asservie à l'imposture (Ramirez, 2002: 228).

Em conclusão, nos dois contos-romances aqui tratados, Le Sopha e Ah quel Conte!, Crébillon recorre à extravagância como forma de problematização do exotismo maravilhoso em voga na literatura coeva, propondo uma reflexão sobre questões de natureza moral e política. Metempsicose, metamorfoses, encantamentos e outros motivos do género maravilhoso alimentam a imaginação criadora do autor. Este, contudo, fiel à ironia da sua poética do jogo, utiliza a bizarria feérica e orientalizante para criticar os costumes, à maneira da comédia molieresca. O desvelar decente das máscaras sociais insere-se aqui na constante busca do verdadeiro amor, não o depurado "parfait amour" das Preciosas, mas um sentimento sincero que faça corresponder harmoniosamente "le cœur, l'esprit et les sens", como o do par Phénime e Zulma do Sopha. Estes contos galantes orientais são, como vimos, obras ao serviço de uma visão irónica e céptica da sociedade. 


\section{Bibliografia}

Carvalho, Ana Alexandra Seabra de (2003). O jogo do desejo em Claude Crébillon: Estudo dos processos retóricos da sedução. Lisboa: Fundação Calouste Gulbenkian - Fundação para a Ciência e a Tecnologia.

CAzEnobe, Colette (1997). Crébillon fils ou la politique dans le boudoir. Paris: Honoré Champion.

CITTON, Yves (1994). Impuissances: Défaillances masculines et pouvoir politique de Montaigne à Stendhal. Paris: Aubier.

CONROY, Peter (1972). Crébillon fils: Techniques of the Novel. Oxford: Voltaire Foundation.

CREBILLON, Claude (1999). CEuvres complètes I. Paris: Classiques Garnier Multimédia.

Crebillon, Claude (2000). CEuvres complètes II. Paris: Classiques Garnier Multimédia.

CREBILLON, Claude (2001). CEuvres complètes III. Paris: Classiques Garnier Multimédia.

Crebillon, Claude (2002). CEuvres complètes IV. Paris: Classiques Garnier Multimédia.

DAGEN, Jean (1995). Introduction à la sophistique amoureuse dans Les Égarements du cœur et de l'esprit de Crébillon fils. Paris: Honoré Champion.

DORNIER, Carole (1994). Le discours de maîtrise du libertin: Étude sur l'œuvre de Crébillon fils. Paris: Klincksieck.

FORT, Bernadette (1978). Le langage de l'ambiguïté dans l'œuvre de Crébillon fils. Paris: Klincksieck.

FUNKE, Hans-Günter (1972). Crébillon fils als Moralist und Gesellschaftskritiker. Heidelberg: Carl Winter Universitätsverlag.

GENETTE, Gérard (1987). Seuils. Paris: Éditions du Seuil.

GeRAud, Violaine (1995). La lettre et l'esprit de Crébillon fils. Paris: SEDES.

GIARD, Anne (1986). Savoir et récit chez Crébillon fils. Paris-Genève: Champion-Slatkine.

HARTMANN, Pierre (1998). Le contrat et la séduction: Essai sur la subjectivité amoureuse dans le roman des Lumières. Paris: Honoré Champion.

JOMAND-BAUDRY, Régine (1996). "Lectures du récit dans Ah quel conte! de Crébillon fils". In: Recherches et Travaux, no 51, pp. 105-119.

JOMAND-BAUDRY, Régine (2002). "La genèse de Ah quel conte! de Crébillon fils ou la fabrique du conte". In: Régine Jomand-Baudry e Jean-François Perrin (orgs.). Le conte merveilleux au XVIIle siècle: Une poétique expérimentale. Paris: Éditions Kimé, pp. 87-101.

JOSEPH, Jean René (1984). Crébillon fils: économie érotique et narrative. Lexington, Kentucky: French Forum Publisher.

RAMIREZ, Carmen (2002). "Le soupçon du merveilleux dans le conte des Lumières". In: Régine Jomand-Baudry e Jean-François Perrin (orgs.). Le conte merveilleux au XVIIle siècle: Une poétique expérimentale. Paris: Éditions Kimé, pp. 212-228.

SGARD, Jean (org.) (1996). Songe, illusion, égarement dans les romans de Crébillon. Grenoble: ELLUG, Université Stendhal.

SIEMEK, Andrzej (1981). La recherche morale et esthétique dans le roman de Crébillon fils. Oxford: Voltaire Foundation.

StEWART, Philip (1973). Le Masque et la Parole: le langage de l'amour au XVIIle siècle. Paris: Librairie José Corti.

STURM, Ernest (1970). Crébillon fils et le libertinage au XVIIle siècle. Paris: Nizet.

VERSINI, Laurent (1968). Laclos et la tradition: essai sur les sources et la technique des Liaisons dangereuses. Paris: Klincksieck. 
VIART, Thierry (1999). La convention de l'amour-goût chez Claude Crébillon: genèse et perspectives. Oxford: Voltaire Foundation.

WAGNER, Horst (1972). Crébillon fils: die erzählerische Struktur seines Werkes. München: Walter Fink Verlag. 